\title{
Pengembangan bahan ajar ipa dengan pendekatan SETS (science, enviroment, technology and society) pada tema bioteknologi untuk kelas IX SMP/MTS
}

\author{
Widiya Lutfiani, Safwatun Nida*, Erni Yuliati \\ Universitas Negeri Malang, Jl. Semarang No. 5 Malang, Jawa Timur, Indonesia \\ *Penulis korespondensi, Surel: safwatun.nida.fmipa@um.ac.id
}

Paper received: 01-04-2021; revised: 15-04-2021; accepted: 30-04-2021

\begin{abstract}
Abstrak
Kurikulum 2013 mengharapkan agar siswa dapat mengaitkan antara sains, teknologi, lingkungan dan masyarakat. Namun dalam pembelajaran IPA saat ini, bahan ajar yang digunakan terlalu fosus pada konsep sains dan kurang mengaitkan antara sains, lingkungan, teknologi dan masyarakat. Tujuan dari penelitian ini adalah untuk menghasilkan bahan ajar IPA dengan pendekatan SETS pada tema bioteknologi untuk siswa kelas IX SMP/MTs yang valid dan layak. Pengembahan bahan ajar ini mengadaptasi model pengembangan 4D dari Thiagarajan. Hasil validasi materi dalam bahan ajar dinyatakan sangat valid dengan persentase 97 persen, penyajian buku siswa dinyatakan sangat valid dengan persentase 82 persen, sedangkan untuk penyajian buku guru dinyatakan sangat valid dengan persentase 88 persen. Hasil uji keterbacaan menunjukkan bahwa buku siswa sangat layak dengan persentase 94 persen dan buku guru sangat layak dengan persentase 95 persen. Berdasarkan hasil yang diperoleh dapat disimpulkan bahwa bahan ajar IPA yang dihasilkan telah valid dan layak.
\end{abstract}

Kata kunci: Bahan Ajar; Pendekatan SETS; Bioteknologi.

\section{Pendahuluan}

Sistem pendidikan di Indonesia saat ini mengacu pada kurikulum 2013. Pembelajaran IPA berdasarkan kurikulum 2013 dilaksanankan secara terpadu. Melalui Permendikbud no. 20 tahun 2016 tentang Standar Kompetensi Lulusan (SKL) menyatakan bahwa ilmu pengetahuan maupun teknologi yang didapatkan siswa selama pembelajaran diharapkan dapat dikaitkan dalam masyarakat dan lingkungan alam sekitar. Sehingga dalam pembelajaran IPA diharapkan dapat membantu siswa dalam mengaitan antara sains, teknologi, lingkungan dan masyarakat.

Berdasarkan studi lapangan di tiga sekolah di Kota Malang, pelaksanaan pembelajaran IPA di sekolah terkendala permasalahan bahan ajar. Bahan ajar yang digunakan dalam pembelajaran IPA saat ini terlalu berfokus pada pemahaman konsep sains dan kurang mengaitkan konsep sains tersebut dengan kehidupan sehari-hari termasuk kaitan antara sains dengan lingkungan dan masyarakat. Pembelajaran IPA yang terlalu fokus terhadap konsep mengakibatkan literasi sains siswa untuk berfikir dalam menyelesaikan masalah menjadi rendah (Pantiwati \& Husamah, 2014; Odja \& Payu, 2014).

Salah satu yang dibutuhkan dalam pembelajaran IPA adalah bahan ajar yang mengaitkan konsep sains dalam kehidupan. Bahan ajar IPA yang disajikan dengan mengaikat konsep IPA dalam kehidupan sehari-hari menggunakan pendekatan SETS (Science, Environment, Technology and Society) dapat meningkatkan kemampuan berpikir siswa sehingga hasil belajar siswa dalam mata pelajaran sains menjadi meningkat (Yoruk, 2010: 1422; Lau, 2013; Yuliati 2013). Pendekatan ini memungkinkan siswa dapat melihat integrasi antara IPA dalam teknologi, lingkungan dan masyarakat (Listiyono, 2012; Nugraha, 2013). 
Sehingga pembelajaran dengan pendekatan SETS menjadi lebih bermakna (MacLeod, 2013:11)

Bioteknologi merupakan salah satu materi dalam mata pelajaran IPA. Produk bioteknologi telah banyak ditemui dalam kehidupan sehari-hari. Berdasarkan pada Kompetensi Dasar (KD) 3.7 kelas IX SMP/MTs yakni menerapkan konsep bioteknologi dan peranannya dalam kehidupan, penerapan bioteknologi telah memberikan dampak bagi lingkungan hingga berperan dalam kesejahteraan masyarakat. Sehingga materi bioteknologi ini sesuai jika diajarkan dengan pendekatan Science, Environment, Technology and Society (SETS) (Milah dkk., 2012).

Bahan ajar dengan pendekatan SETS pada tema bioteknologi merupakan bahan ajar yang mengaitkan materi bioteknologi kedalam aspek sains, teknologi, lingkungan dan masyarakat. Bahan ajar tersebut sebelumnya telah dikebangkan oleh Milah dkk (2012) yang efektif terhadap hasil belajar dan ketuntasan siswa. Akan tetapi, bahan ajar yang dikembangkan ditujukan untuk siswa kelas XII SMA/MA. Bahan ajar tersebut kurang sesuai jika digunakan dalam pembelajaran IPA di SMP karena KD pada jenjang SMP berbeda dengan KD pada jenjang SMA.

Tujuan dari penelitian ini adalah untuk menghasilkan bahan ajar IPA dengan pendekatan SETS pada tema bioteknologi yang valid dan layak.

\section{Metode}

Penelitian ini dilakukan dengan mengadaptasi model pengembangan 4D oleh Thiagarajan dkk. (1974). Model ini terdiri dari 4 tahap pengembangan, yaitu define, design, develop, dan disseminate. Pada penelitian ini tahapan yang dilakukan hanya tahap define, design, dan develop. Pada tahap define dilakukan analisis permasalahan utama dalam pembelajaran IPA. Selanjutnya, ditentukan solusi untuk mengatasi permasalahan tersebut, yaitu pengembangan bahan ajar dengan pendekatan SETS. Tahapan design merupakan langkah dalam merancang bahan ajar sesuai dengan analisis pada tapat define. Bahan ajar yang sudah disusun kemudian divalidasi oleh validasi ahli materi dan ahli bahan ajar pada tahap develop.

Setelah bahan ajar dinyatakan valid, selanjutnya dilakukan uji keterbacaan terhadap 2 guru IPA dan 10 siswa yang telah menempuh materi bioteknologi di SMP. Jenis data yang diperoleh dapat dikelompokkan menjadi dua, yaitu data kuantitatif berupa skor angket dan data kualitatif berupa saran serta komentar. Skala yang digunakan dalam angket berupa skala likert, kecuali untuk kebenaran konsep menggunakan skala gutman. Data kuantitatif dianalisis dan dihitung persentase rata-ratanya. Bahan ajar dianggap valid dan layak bila persentasenya $\geq 61 \%$. 


\section{Hasil dan Pembahasan}

Bahan ajar yang dikembangkan dalam penelitian ini terdiri dari buku siswa dan buku guru.

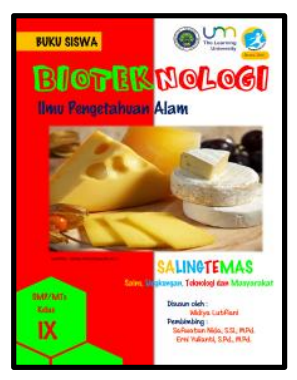

(a)

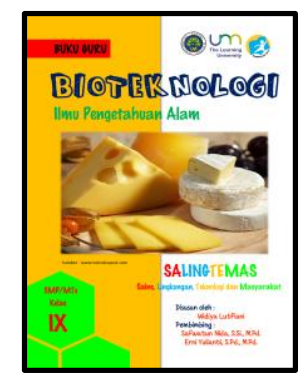

(b)

Gambar 1. Bahan ajar: a) buku siswa, b) buku guru

Buku siswa terdiri dari: a) cover, b) kata pengantar, c) petunjuk penggunaan buku, d) daftar isi, e) peta konsep, f) materi bioteknologi, g) diskusi salingtemas, h) uji pemahaman. Materi bioteknologi dalam bahan ajar terdiri dari tiga bab yakni, konsep bioteknologi, bioteknologi konvensional dan bioteknologi modern. Aspek sains, teknologi, lingkungan dan masyarakat dalam bahan ajar disajikan secara terpadu. Misalnya dalam materi produk bioteknologi tempe, dalam bahan ajar dijelaskan teknologi proses pembuatan tempe, konsep sains yang telibat dalam pembuatan tempe, peranan tempe bagi masayarakat di Indonesia dan dampak tempe bagi lingkungan secara terpadu.

Buku guru terdiri dari: a) cover, b) kata pengantar, c) daftar isi, d) kompetensi inti, kompetensi dasar, indikator dan tujuan pembelajaran, e) materi esensial dan alokasi waktu, f) langkah pembelajaran, g) teknik penilaian, h) soal evaluasi, i) RPP, j) kisi-kisi soal evaluasi. Bugu guru terdapat soal evaluasi yang terdiri dari 39 soal pilihan ganda yang telah dinyatakan valid dengan persentase $81-85 \%$ dan 5 soal uraian yang telah dinyatakan valid dengan persentase $81,3-93,8 \%$.

Hasil analisis data validari ahli materi dapat dilihat pada tabel dibawah ini.

Tabel 1. Data dan Analisis Data Hasil Validasi Ahli Materi

\begin{tabular}{lll}
\hline Aspek yang dinilai & $\begin{array}{l}\text { Presentase (\%) } \\
\text { rata-rata skor }\end{array}$ & Kategori kevalidan \\
\hline Indikator dan Tujuan Pembelajaran & 92,0 & sangat valid \\
Aspek SETS & 100,0 & sangat valid \\
Peta Konsep & 92,0 & sangat valid \\
Kedalaman dan keluasan Materi & 100,0 & sangat valid \\
Latihan soal & 100,0 & sangat valid \\
Kebenaran konsep & 100,0 & sangat valid \\
\hline Rata-Rata & 97,0 & sangat valid \\
\hline
\end{tabular}

Berdasarkan penilaian yang diberikan oleh validator ahli materi, kebenaran konsep dalam bahan ajar yang terdiri dari konsep bioteknologi, bioteknologi konvensional dan bioteknologi modern dinyatakan $100 \%$ valid. Sehingga secara umum materi yang disajikan dalam bahan ajar dinyatakan sangat valid dengan persentase kevalidan 97\%. 
Hasil analisis data validari ahli materi dapat dilihat pada tabel dibawah ini.

Tabel 2. Data dan Analisis Data Hasil Validasi Ahli Bahan Ajar (Buku Siswa)

\begin{tabular}{|c|c|c|}
\hline Aspek yang dinilai & $\begin{array}{l}\text { Presentase (\%) } \\
\text { rata-rata skor }\end{array}$ & Katergori kevalidan \\
\hline \multicolumn{3}{|l|}{ Kelayakan Isi } \\
\hline Cakupan materi & 83,0 & sangat valid \\
\hline Keakuratan materi & 75,0 & Valid \\
\hline Aspek SETS & 90,0 & sangat valid \\
\hline Komponen buku siswa & 80,0 & Valid \\
\hline \multicolumn{3}{|l|}{ Kelayakan Kebahasaan } \\
\hline $\begin{array}{l}\text { Kesesuaian bahasa dengan } \\
\text { tingkat perkembangan siswa }\end{array}$ & 75,0 & Valid \\
\hline $\begin{array}{l}\text { Kesesuaian dengan kaidah } \\
\text { Bahasa Indonesia }\end{array}$ & 75,0 & Valid \\
\hline \multicolumn{3}{|l|}{ Kelayakan Penyajian } \\
\hline Teknik penyajian buku siswa & 87,0 & sangat valid \\
\hline Kejelasan tujuan & 100,0 & sangat valid \\
\hline Pendekatan SETS & 100,0 & sangat valid \\
\hline \multicolumn{3}{|l|}{ Kelayakan Desain } \\
\hline Penggunaan font & 75,0 & Valid \\
\hline Tata letak & 75,0 & Valid \\
\hline Ilustrasi, Gambar dan foto & 75,0 & Valid \\
\hline Rata-rata & 82,5 & Sangat valid \\
\hline
\end{tabular}

Berdasarkan peilaian dari validator ahli bahan ajar untuk buku siswa IPA dengan pendekatan SETS pada tema bioteknologi dinyatakan sangat valid dengan persentase kevalidan $82,5 \%$.

Tabel 3. Data dan Analisis Data Hasil Validasi Ahli Bahan Ajar (Buku Guru)

\begin{tabular}{lll}
\hline Aspek yang dinilai & $\begin{array}{l}\text { Presentase (\%) } \\
\text { rata-rata skor }\end{array}$ & Katergori kevalidan \\
\hline $\begin{array}{l}\text { Kelayakan Isi } \\
\text { Komponen buku guru }\end{array}$ & 88,0 & sangat valid \\
$\begin{array}{l}\text { Kelayakan Kebahasaan } \\
\text { Kesesuaian bahasa }\end{array}$ & 75,0 & Valid \\
$\begin{array}{l}\text { Kesesuaian dengan kaidah } \\
\text { Bahasa Indonesia }\end{array}$ & 92,0 & sangat valid \\
$\begin{array}{l}\text { Kelayakan Penyajian } \\
\text { Teknik penyajian buku guru }\end{array}$ & 100,0 & \\
Kejelasan tujuan & 100,0 & sangat valid \\
$\begin{array}{l}\text { Pendekatan SETS } \\
\text { Kelayakan Desain }\end{array}$ & 100,0 & sangat valid \\
$\begin{array}{l}\text { Penggunaan font } \\
\text { Tata letak }\end{array}$ & 75,0 & sangat valid \\
\hline Rata-rata & 75,0 & Valid \\
\hline & $\mathbf{8 8 , 0}$ & Valid \\
\hline
\end{tabular}

Berdasarkan peilaian dari validator ahli bahan ajar untuk buku guru dinyatakan sangat valid dengan persentase kevalidan $88 \%$. 
Data kualitatif berupa saran dan komentar yang diberikan oleh validator terkait dengan materi dan penyajian bahan ajar dijadikan pertimbangan untuk melakukan revisi bahan ajar. Komentar dan saran yang diberikan oleh validator dapat dilihat pada Tabel 4 .

\section{Tabel 4. Komentar dan Saran oleh Validator}

\begin{tabular}{l}
\hline Komentar dan saran \\
\hline Perlu ditambahkan beberapa konsep-konsep penting seperti kawin silang, bayi \\
tabung dan kit diagnostik \\
Perlu diperhatikan penggunaan tanda titik dan koma dalam penulisan bahan ajar \\
Redaksi penulisan perlu diperbaiki sesuai dengan saran yang telah ditandai pada soal \\
evaluasi, buku siswa maupun buku guru \\
Ukuran tulisan pada keterangan Gambar diperkecil dan sumber Gambar diletakkan \\
dibawah keterangan Gambar
\end{tabular}

Setelah produk dinyatakan valid oleh validator ahli materi dan ahli bahan ajar, kemudian dilakukan ujicoba keterbacaan terhadap 10 siswa dan dua guru IPA SMP uji menguji kelayakan bahan ajar yang dihasilkan. Hasil dari uji keterbacaan buku siswa dinyatakan layak untuk digunakan dengan persentase 94\%, sedangkan untuk guru layak digunakan dengan persentase $95 \%$

\section{Simpulan}

\subsection{Kesimpulan}

Berdasarkan hasil validasi menunjukkan materi yang disajikan valid dengan persentase 97\%, penyajian buku siswa valid dengan persentase $82,5 \%$, sedangkan buku guru valid dengan persentase $88 \%$. Hasil uji keterbacaan menunjukkan bahwa buku siswa layak dengan persentase $94 \%$ dan buku guru layak dengan persentase 95\%. Berdasarkan hasil tersebut dapat disimpulkan bahwa bahan ajar IPA dengan pendekatan SETS pada tema bioteknologi untuk siswa kelas IX SMP/MTs yang dihasilkan telah valid dan layak.

\subsection{Saran}

Saran untuk pengembangan bahan ajar yang lebih lanjut adalah: 1) menguji keefektifan bahan ajar IPA dengan pendekatan SETS pada tema bioteknologi dalam pembelajaran di kelas, 2) menguji kevalidan dan kereabilitasan soal evaluasi yang disajikan dalam buku guru, 3) menghasilkan bahan ajar IPA dengan pendekatan SETS pada tema yang lain.

\section{Daftar Rujukan}

Lau, K. C. (2013, June). Impacts of a STSE high school biology course on the scientific literacy of Hong Kong students. In Asia-Pacific Forum on Science Learning and Teaching (Vol. 14, No. 1, pp. 1-25). Hong Kong Institute of Education. 10 Lo Ping Road, Tai Po, New Territories, Hong Kong.

Listiyono. (2012). Pendidikan Karakter dan pendekatan SETS (Science, Enviroment, Tecnology and Society) dalam perancanaan Pembelajaran sains. Jurnal Phenomenon, 2 (1).

MacLeod, K. (2014). Pre-Service Teachers' Perceptions of Teaching STSE-Based High School Physics: Implications for Post-Secondary Studies. European Journal of Physics Education, 5(1), 1-15.

MILLAH, E. S. (2012). Pengembangan buku ajar materi bioteklogi di kelas XII SMA IPIEMS Surabaya berorientasi sains, teknologi, lingkungan, dan masyarakat (SETS). Berkala Ilmiah Pendidikan Biologi (BioEdu), 1(1). 
Nugraha, D. A., \& Binadja, A. (2013). Pengembangan bahan ajar reaksi redoks bervisi SETS, berorientasi konstruktivistik. Journal of Innovative Science Education, 2(1).

Odja, A. H. dkk, Analisis Kemampuan Awal Literasi Sains Siswa Pada Konsep IPA. Jurnal Jurusan Kimia FMIPA Universitas Negeri Surabaya ISSN, 978-602.

Pantiwati, Y., \& Husamah, H. (2016). Analisis kemampuan literasi sains siswa SMP Kota Malang. Research Report.

Nuray, Y., \& Morgil, I. (2010). The effects of science, technology, society, environment (STSE) interactions on teaching chemistry. Natural science, 2(12), 1417.

Yuliati, L. (2013). Efektivitas bahan ajar IPA terpadu terhadap kemampuan berpikir tingkat tinggi siswa SMP. Jurnal Pendidikan Fisika Indonesia, 9(1). 